\title{
RAFAEL LARCO HOYLE: 1901-1966
}

\section{Clifford Evans}

TN HIS BOOK Peru (1966), summarizing his 1 ideas about the origin and sequences of PreColumbian Peruvian cultures, Larco paid tribute to the role of the three great pioneers in Peruvian Archaeology - Max Uhle, Julio C. Tello, and Alfred Kroeber. Rafael Larco Hoyle is the fourth. The archaeology of the North Coast of Peru today is based on his contributions, including definition of such cultures as Cupisnique (the North Coastal Formative period expression of the Chavinoid horizon) and Salinar (the distinctive white-on-red Late Formative period culture with broader connections to the north in Ecuador and to the south in parts of Peru), and redefinition of Mochica into subperiods, as well as description of Mochica ethnography from the details shown on the painted and modeled pottery.

Don Rafael, or Ray as he was known to his English-speaking friends and colleagues, was born on May 18, 1901, at Hacienda Chiclin, Chicama Valley, near Trujillo, Peru, son of Don Rafael Larco Herrera and Doña Esther Hoyle de Larco. Raised on the sugar hacienda with his younger brothers, Constante (surviving) and Javier, he received his primary school education in Trujillo in the Instituto Moderno de Trujillo, Colegio Ntra. Señora de Guadalupe, and the Barranco English Institute. In 1914, he was sent to secondary school in the United States and entered the Tome High School in Maryland. While there, he was one of the outstanding high school athletes in the State of Maryland, especially in football, although he was also active in baseball, soccer, and athletics in general. In 1919 he entered Cornell University to study agriculture and then attended as a special, non-degree student New York University's School of Engineering in 1922 and the School of Commerce in 1923, where he studied business administration and finance. The primary purpose of this United States education was not to obtain formal degrees, but to study engineering with a view to mechanization of the sugar industry on the family hacienda, to become familiar with the problems of welfare, education, and organization of the sugar workers and their families, and to develop a practical understanding of business operations. To further these studies, he also traveled to Cuba, Puerto Rico, Europe, and Hawaii.
Returning to Peru in late 1923, he applied this business and engineering knowledge to the family interests in Chicama Valley and became president of the Directorio Ejecutiva de Negociacion Chiclin and Hacienda Salamanca. These haciendas became famous in the north for outstanding stock raising and for breaking records in sugar production per hectare and sugar per metric ton of cut cane, the result of having been the first to introduce mechanical production on the north coast. In addition, under his direction the family developed a model sugar hacienda at Chiclin, including hospitals, clinics, and schools with advanced systems of education and modern teaching methods.

Around 1924, Larco's interest in the archaeology of his country began as a result of his father's influence. On the Hacienda Chiclin, he had lived in a museum atmosphere since a few years after his birth because his famous father had begun in 1903 to assemble a collection of North Peruvian pre-Columbian pottery. While later traveling in Europe, Rafael Larco Herrera visited the Museo del Prado in Madrid and noticed that their collection of Peruvian archaeological materials was poor. He consequently donated his entire archaeological collection to Spain, and today it is on exhibit in the Museo Arqueológico in Madrid.

From this first archaeological collection, one outstanding Mochica portrait vessel was kept, and this formed the nucleus of a new archaeological collection. In 1925, Larco's father acquired 600 pottery vessels and other archaeological objects from his brother-in-law, Alfredo Hoyle, and a smaller collection from Dr. Mejía, and he gave the entire collection to his son, Don Rafael. Although the latter had shown some interest by this time in Peru's past, this collection inspired him to develop a museum and to study intensively Peru's archaeology. From this moment onward, Larco increased the collection, by buying specimens from Chicama Valley and nearby Trujillo, Virú, and Chimbote valleys in the north, and later from other parts of Peru, but always specializing in North Peru. The collection grew so rapidly that it had to be installed in a separate building on the Hacienda Chiclin, which was inaugurated as the Museo Rafael Larco Herrera on July 28, 1926, to protect the 


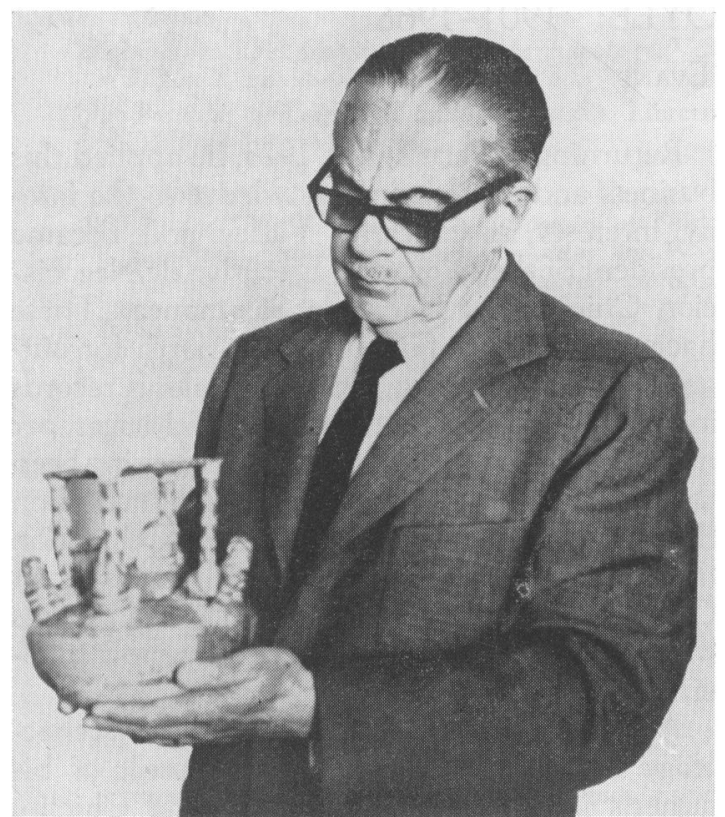

Rafael Larco Hoyle

archaeological riches of Peru and as a monument to his father, who was still living.

In 1933, two large private collections were acquired, one of over 3,000 pieces from $\mathrm{Mr}$. Carranza in Trujillo, and the other with 8,000 pieces of pottery, metal, and textiles from Carlos A. Roa of the Hacienda Clara in the Santa Valley. Transferral of the Roa collection without breakage from Santa Valley to Chicama Valley was a major operation, since the Pan American Highway did not yet exist. After two weeks everything was packed with straw in wooden boxes and was loaded into trucks which drove along the beach at low tide. Everything arrived in good condition, but then the job of removing the salt impregnated in the pottery had to be undertaken, since this had never before been done. One of the largest swimming pools on Hacienda Chiclin was commandeered for archaeology. The pots were submerged, and they soaked over a period of two months, during which 15 boys kept the water changed as it became contaminated with dissolved salt. After this treatment, the vessels could be stored and exhibited free of the damaging salt crystals.

At the same time Don Rafael was buying collections, he also began extensive explorations and excavations in the desolate foothills, valleys, and talus slopes of the Virú Valley and Chicama Valley and its branches, such as Cupisnique Quebrada. This field work became a family affair, with everyone showing the same enthusiasm and love of the work in developing the collections of the Museum. Don Rafael and his brothers, Constante and Javier, his wife Isolina and their two daughters, Isabel and Carola, and their close friend Enrique Jacobs, of Trujillo, spent considerable time together in the field. Much valuable data on gravelot association were recorded, information which would be of great help to scholars if it could be published. From this continued activity, the museum grew until at his death in 1966 it contained some 40,000 complete pottery vessels and thousands of metal, textile, wood, and other artifacts. On the Hacienda Chiclin, it filled 17 rooms, and the overflow was so great that a provisional roof had been built between two buildings to house specimens in long rows, out of the weather.

In 1949, family business interests took Don Rafael from the north coast to Lima. To be separated from his collections would have meant cessation of his archaeological research, as well as "un duro golpe para mi espiritu" (1964: 20). $\mathrm{He}$ also felt that the collections would be more accessible to scholars, scientists, and interested persons if located in the capital. Therefore, a decision was made to move the entire collection to Lima, to construct a new Museum, and to create a Foundation to guarantee the permanence of the Museum and the maintenance of the collections. The new Museo Rafael Larco Herrera was not only constructed in the architectural style of Trujillo of the early 1700's, but it incorporates grills, doors, columns, beams, and brackets from the manor house of the Marqueses de Herrera y Villahermosa in Trujillo. When he was mayor of Trujillo, Don Rafael had tried to protect the house as a national historical monument, since it was one of the best surviving examples of Colonial architecture. Later, political interests, however, allowed the house to be destroyed. Although these few salvaged items give the Museum in Lima a colonial flavor, in all other aspects it is modern. It contains 6 exhibit halls plus a vault for exhibition of the gold and silver, 11 storage rooms, 4 offices serving as library, laboratory and work room, and a garden, patio, and terrace where the largest stone objects are displayed. Plans at the time of Larco's death included the addition of a conference room. Don Rafael was particularly proud of the fact that the Museo Rafael Larco Herrera, with all its collections, publications of the Museum, the staff, the build- 
ings, and the new Foundation, had all been developed privately, without any direct or indirect governmental assistance.

The move to Lima did permit Don Rafael to continue his archaeological studies, and in recent years he began to publish again after a lapse of 12 years (1948-1960), during which he was deeply involved in family business interests and handicapped by poor health. He was an active member of the Boards of Directors of various companies, including the Banco Comercial del Peru, Rayon Peruana, Rayon Celanese, Quimica El Pacífico, Cia. de Seguros El Sol, Cia. Pesquera Consa, and Amial del Peru. Earlier he had founded the newspaper, Diario "La Nación," in Trujillo, and then succeeded his father as president of the Board of Directors of the Diario "La Crónica" in Lima. All of these activities detracted from the time he could spend on archaeology.

Ray was a strong-willed person with a positive personality. Beneath a highly dignified manner, he was outstandingly generous. Always delighted to help qualified scholars, he would willingly put his materials at their disposal. $\mathrm{He}$ could be equally negative to those whom he felt were wasting his time, being motivated by curiosity or seeking a special favor. As a young graduate student assistant of William Duncan Strong on the 1946 Virú Valley Project, I remember many a pleasant Sunday at Hacienda Chiclin when Don Rafael favored the group (including Strong, Bennett, Willey, Ford, Bird, and Collier) with his ideas about Peruvian archaeology. Afterwards, we always enjoyed the magnificent hospitality of the entire Larco family at a sumptuous and delicious midday meal. Then we would retire to the study with an offer of high-quality imported cigars and brandy or some special aged "chicha" made on the Hacienda for pleasant conversations on economics, politics, and the problems of sugar plantations. But always sooner or later the conversation would return to Peruvian archaeology. During these sessions, I was always amazed how, although at times he had not had time to read the latest article or monograph on archaeology in his excellent library, Larco exhibited an intimate knowledge of the tens of thousands of objects in his Museum. He had such a photographic memory of the collections and the ethnographic details shown on some of the pottery that he could often settle arguments by bringing out a specimen that proved his point.
This intimate knowledge of the thousands of objects in the Museum collections was reflected in Larco's outstanding contributions to mythology and socio-political structure of the Mochica, based on scenes on the painted and modeled vessels; his analysis of modification of the spout forms of Mochica vessels, which permitted subdivisions into sub-periods; and the detailed studies of the erotic pre-Columbian pottery, to mention just a few publications. He always undertook each project with intensity and thoroughness, documenting the argument with a large number of specimens. His major professional fault was his failure to document fully the basis for his conclusions, which stemmed in part from the multiple demands on his time. His last books were produced under great pressure and haste. Shortly before his death from a heart attack in Lima on October 23, 1966, he was working on a new well-illustrated monograph on wooden keros, based on what is probably the largest kero collection assembled in any one museum.

Through his drive and determination to let nothing get in his way, Don Rafael Larco Hoyle not only managed well the properties of the family but advanced North Coastal Peruvian archaeology at a time when little was known of the sequential development of the preColumbian cultures of that region. His classic contributions to the Formative period have withstood the test of time. He directed and hosted so well the 1946 Chiclin Conference on North Peruvian Archaeology, at the close of the Viru Valley Project, that it is unfortunate that other such conferences could not have been organized to facilitate the exchange of ideas. Tragically, his poor health over the past decade, his preoccupation with family business, and his limited time for archaeology isolated him from the international scientific community to which he had contributed so much. However, his publications, the collections of the Museo Rafael Larco Herrera, and their perpetuation through the creation of a Foundation to manage and direct the Museum, have assured for Rafael Larco Hoyle the position as the fourth great pioneer in Peruvian archaeology.

\section{Bibliography of Rafael Larco Hoyle 1938}

Los Mochicas, Tomo I. Casa Editora, Lima. 140 pp. 1939

Los Mochicas, Tomo II. Empresa Editorial "Rimac," Lima. 165 pp. 
1941

Los Cupisniques: Trabajo presentado al Congreso Internacional de Americanistas de Lima XXVII Sesion. Casa Editora "La Cronica" y "Variedades," Lima. 259 pp.

1942

La Escritura Mochica sobre Pallares. Revista Geográfica Americana, Año IX, Vol. 18, pp. 93-103. Buenos Aires.

1943

La Escritura Peruana sobre Pallares. Revista Geogräfica Americana, Año IX, Vol. 20, pp. 1-36. Buenos Aires.

1944

La Escritura Peruana Pre-Inca. El Mexico Antigıso, Vol. 6, Nos. 7-8, pp. 219-38. Mexico.

1945

La Cultura Virüi-Buenos Aires. 28 pp.

Los Cupisniques. Buenos Aires. 25 pp.

Los Mochicas. Buenos Aires. 42 pp.

La Cultura Salinar. Una civilización remota del Peru pre-incaico. Revista Geográfica Americana, Vol. 23, No. 141, pp. 327-36. Buenos Aires.

\section{6}

A Culture Sequence for the North Coast of Peru. In "Handbook of South American Indians," edited by Julian H. Steward, Vol. 2, pp. 149-75. Bureau of American Ethnology, Bulletin 143. Washington.

\section{8}

Cronología arqueológica del norte del Perú. Sociedad Geográfica Americana. Buenos Aires. 87 pp.
1960

La Cultura Santa. In Antiguo Perú, Espacio y Tiempo, pp. 235-9. Lima.

1962

La Cultura Santa. Lima. 28 pp.

La Divinidad Felínica de Lambayeque. Lima. 14 pp.

1963

Las Epocas Peruanas. Lima. $83 \mathrm{pp}$.

1964

Museo "Rafael Larco Herrera." Lima. 39 pp.

1965

La Cerámica de Vicus. Lima. 46 pp.

Escultura litica del Peru pre-Colombino. Instituto de Arte Contemporaneo, Serie: Origines del arte PeruanoNo. 2: Escultura litica. Lima. $34 \mathrm{pp}$.

Checan: Essay on Erotic Elements in Peruvian Art. Nagel Publishers, Geneva. 146 pp.

1966

Archaeologia Mundi: Peru. Nagel Publishers, Geneva. Also in French and German editions. 243 pp.

1967

La Cerámica de Vicús y sus nexus con las demas culturas, No. 2. Lima. $111 \mathrm{pp}$.

Los Mochicas

In press for 1968 release:

Los Keros

Texto Escolar

SMITHSONIAN INSTITUTION

Washington, D.C.

October, 1967 